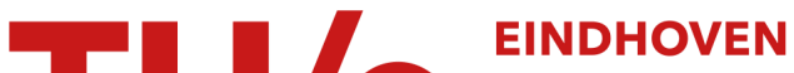 \\ UNIVERSITY OF \\ TECHNOLOGY
}

\section{Determination of uric acid in serum using isotachophoresis}

Citation for published version (APA):

Verheggen, T. M. M., Mikkers, F. E. P., Everaerts, F. M., Oerlemans, F., \& Bruijn, de, C. H. M. M. (1980).

Determination of uric acid in serum using isotachophoresis. Journal of Chromatography, B: Biomedical Sciences and Applications, 182(3), 317-324. https://doi.org/10.1016/S0378-4347(00)81480-2

DOI:

10.1016/S0378-4347(00)81480-2

Document status and date:

Published: 01/01/1980

\section{Document Version:}

Publisher's PDF, also known as Version of Record (includes final page, issue and volume numbers)

\section{Please check the document version of this publication:}

- A submitted manuscript is the version of the article upon submission and before peer-review. There can be important differences between the submitted version and the official published version of record. People interested in the research are advised to contact the author for the final version of the publication, or visit the $\mathrm{DOI}$ to the publisher's website.

- The final author version and the galley proof are versions of the publication after peer review.

- The final published version features the final layout of the paper including the volume, issue and page numbers.

Link to publication

\section{General rights}

Copyright and moral rights for the publications made accessible in the public portal are retained by the authors and/or other copyright owners and it is a condition of accessing publications that users recognise and abide by the legal requirements associated with these rights.

- Users may download and print one copy of any publication from the public portal for the purpose of private study or research.

- You may not further distribute the material or use it for any profit-making activity or commercial gain

- You may freely distribute the URL identifying the publication in the public portal.

If the publication is distributed under the terms of Article 25fa of the Dutch Copyright Act, indicated by the "Taverne" license above, please follow below link for the End User Agreement:

www.tue.nl/taverne

Take down policy

If you believe that this document breaches copyright please contact us at:

openaccess@tue.nl

providing details and we will investigate your claim. 
Journal of Chromatography, 182 (1980) 317-324

Biomedical Applications

Q Elsevier Scientific Publishing Company, Amsterdam - Printed in The Netherlands

CHROMBIO. 534

DETERMINATION OF URIC ACID IN SERUM USING ISOTACHOPHORESIS

Th. VERHEGGEN, F. MIKKERS and F. EVERAERTS

Department of Instrumental Analysis, Eindhoven University of Technology, Eindhoven (The Netherlands)

and

F. OERLEMANS and C. DE BRUYN

Department of Human Genetics, Faculty of Medicine, University of Nijmegen, Nijmegen (The Netherlands)

(Received November 22nd, 1979)

\section{SUMMARY}

An operational system is described for the isotachophoretic determination of uric acid in serum, making use of column coupling. The method has been compared with a standard enzymatic procedure. With the present technique small amounts of serum (ca. $3 \mu 1$ ) can be applied without any pretreatment. Urate recovery was 99.0-100.5\%. Under the non-physiological measuring conditions used, 12-28\% of control serum uric acid was bound to macromolecules of molecular weight exceeding 25,000. The day-to-day variations of the isotachophoretic procedure were smaller than those of the enzymatic method, whereas standard deviations were comparable. The isotachophoretic procedure is less influenced by certain metabolites.

\section{INTRODUCTION}

Uric acid is the end-product of purine catabolism in man. An abnormal concentration of uric acid in body fluids may be indicative of a number of disturbances. An increased level of uric acid in serum (hyperuricemia) is seen in primary gout: although there is a normal excretion rate, uric acid is overproduced or it is underexcreted [1].

In secondary gout, hyperuricemia might result either from increased nucleic acid turn-over (for example, hematologic disorders, leukemia), or from decreased renal excretion of uric acid induced by drugs or dietary factors. Also in a number of genetic disorders, such as glycogen storage disease, Down's syn- 
drome and psoriasis, is hyperuricemia a common feature $[1,2]$.

The methods currently used to assay uric acid in serum and urine are based on either chemical or enzymatic oxidation to allantoin. The enzymatic method seems to be the method of choice because of its sensitivity, accuracy and specificity $[3,4]$. Analytical techniques such as high-performance liquid chromatography (HPLC) and isotachophoresis can be applied for determination in biological fluids of a series of metabolites, including uric acid. Methods using HPLC have been reported for serum urate [5], blood and urine [6]. Isotachophoresis has been employed in the analysis of nucleotides in muscle extracts [7] and urinary purines and pyrimidines, including uric acid [8]. Until now isotachophoresis has not been used for the rapid determination of serum uric acid.

Isotachophoresis is an electrophoretic separation method, taking advantage of the non-diluting phenomenon of the sample zone in the steady-state [9]. In this paper an isotachophoretic procedure is described for the quantification of uric acid in serum.

Unlike other available methods, such as the colorimetric [10] and the enzymatic [3, 4] methods, the determination of uric acid by HPLC and isotachophoresis is much less hampered by interfering substances, such as drugs and biological metabolites. In contrast to the HPLC procedure, where pretreatment of biological samples is often necessary (e.g. removal of proteins), the sample can mostly be applied directly in isotachophoresis. Moreover, the ratio of free to protein-bound urate can be determined conveniently using a simple ultrafiltration step.

\section{MATERIALS AND METHODS}

\section{Materials}

Uric acid (sodium salt), HCl (Titrisol ${ }^{R}$ ), tris(hydrosymethyl)aminomethane (Tris), e-aminocaproic acid (EACA) and morpholino-ethanesulfonic acid (MES), all analytical grade, were purchased from Merck (Darmstadt, G.F.R.). Hydroxyethylcellulose (HEC) was obtained from Polysciences (Warrington, PA, U.S.A.; Cat. No. 5568); a $0.5 \%(\mathrm{w} / \mathrm{v})$ stock solution was purified by ion exchange. Uricase was purchased from Lфvens Kemiska Fabrik (Ballerud, Denmark). Serum was prepared from venous blood after clotting ( $2 \mathrm{~h}$ at room temperature) and centrifugation for $10 \mathrm{~min}$ at $1000 \mathrm{~g}\left(4^{\circ} \mathrm{C}\right)$. The samples were stored at $-20^{\circ} \mathrm{C}$. Ultrafiltration CF 25 centriflow filters (mol. wt. cut-off 25,000 ) were purchased from Amicon (Oosterhout, The Netherlands).

\section{Methodology}

In the present study isotachophoretic equipment was used in which two Teflon capillaries with different internal diameters were mounted [11, 12$]$. This set-up is of special interest for the analysis of biological samples. In such samples constituents are often present at a low concentration and the concentration of various compounds can differ by an order of magnitude. This is the case in serum, for example, where the chloride concentration can exceed the concentration of uric acid by a factor of up to 500. In such mixtures the analysis time required to obtain sufficient information on a given compound in- 
creases when its concentration decreases. The present column coupling system $[11,12]$ alleviates this problem. Basically the equipment consists of two tubes with inside diameters of $0.8 \mathrm{~mm}$ (pre-separation tube) and $0.2 \mathrm{~mm}$ (separation tube). In the pre-separation tube a high electric current is permitted. At a welldefined distance from a "tell-tale" detector (conductivity type), mounted in the pre-separation compartment, a special construction (bifurcation) allows the separation tube to branch off from the pre-separation tube. The zones of interest can be easily selected via the "tell-tale" detector and separated from the "sample-train", migrating isotachophoretically in the pre-separation tube. In fact, the very efficient separation characteristic of isotachophoresis is applied for both sample pre-separation and final separation. A high sample load is permitted without a significant increase in analysis time. High ratios of concentrations between sample constituents are tolerated and different operational systems can be applied in one analysis. Moreover different electrophoretic principles (for example, isotachophoresis and zone electrophoresis) can be applied [9].

The enzymatic determination of serum uric acid was performed in the laboratory of the Department of Neurology (University Hospital, Nijmegen) with an ABA 100 bichromatic analyser (Abbott). The determination of uric acid is based on the successive action of three purified enzymes which are added to the reaction mixture: uricase, catalase and aldehyde dehydrogenase [4]. The formation of NADPH from NADP ${ }^{+}$in the latter reaction (measured at both 340 and $380 \mathrm{~nm}$ ) is used for the quantification of uric acid. Sera containing known concentrations of uric acid were used as standards.

\section{RESULTS}

The operational conditions for the isotachophoretic determination of uric acid are listed in Table I. The leading electrolyte ( $\mathrm{pH}$ 5.0) contains $\mathrm{Cl}^{-}$as the leading ion; the terminating electroly te ( $\mathrm{pH}$ 6.5) consists of morpholino-ethanesulfonic acid and Tris. The analysis time with the column coupling system is $12 \mathrm{~min}$.

Physiological uric acid concentrations normally range between 0.15 and 0.40 $m M$. In Fig. 1 the calibration curve for uric acid in this range is shown. As can be expected in isotachophoresis there is a linear relationship hetween the uric acid zone length and the amount of uric acid injected.

TABLE I

OPERATIONAL SYSTEM FOR THE ISOTACHOPHORETIC DETERMINATION OF URIC ACID

\begin{tabular}{lll}
\hline & Electrolyte & \\
\cline { 2 - 3 } & Leading & Terminating \\
\hline Anion & Chloride & MES \\
Concentration (M) & 0.01 & 0.005 \\
Counter-ion & EACA & Tris \\
pH & 5.00 & 6.5 \\
Additive & $0.25 \%$ HEC & \\
Driving curreat (A) & $20 \times 10^{-6}$ & \\
\hline
\end{tabular}




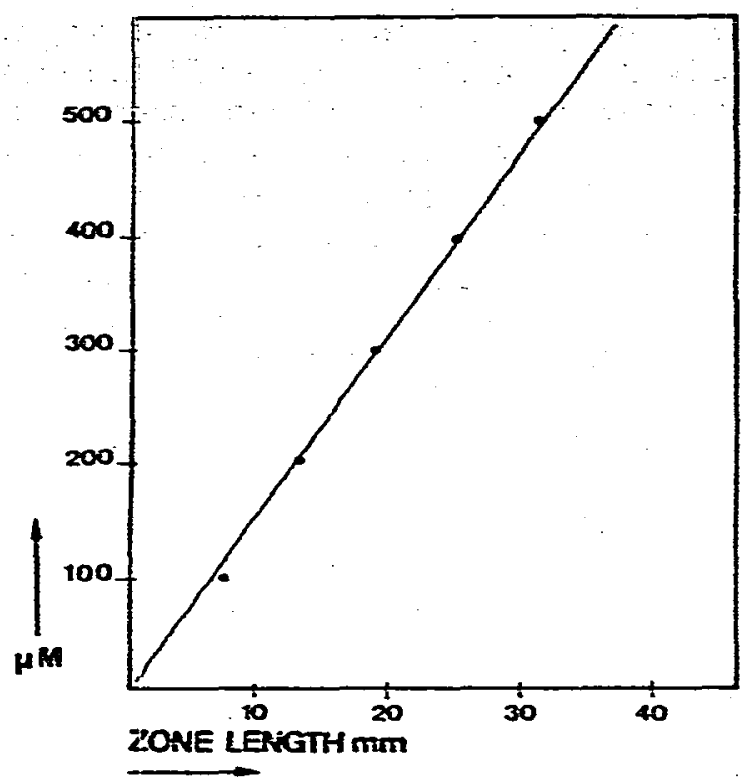

Fig. 1. Calibration curve for uric acid. Operational conditions, see Table I. Injected rolume: $3 \mu \mathbf{l}$.

When standard amounts of uric acid were added to serum, extensively dialysed against $0.9 \% \mathrm{NaCl}$, the isotachophoretic analyses yielded recoveries of 99.0-100.5\% (data not shown). The uric acid zone was eliminated after treatment of the serum with purified uricase. In addition, over-spiking confirmed the identity of the uric acid zone.

In order to estimate the amount of uric acid bound to serum proteins under our experimentai conditions, the recovery from ultrafiltered and non-ultrafiltered samples was compared. When undialysed pooled serum fiom several healthy controls was passed through an Amicon CF 25 filter (mol. wt. cut-off $25,000), 85.1 \%$ of the total serum uric acid was recovered in the ultrafiltrate, indicating that in this sample approximately $15 \%$ was bound to proteins with a molecular weight exceeding 25,000. The lower amount of uric acid in the ultrafiltrate as compared to non-filtered samples was not due to the $\mathrm{CF} 25$ filter; when a standara solution of uric acid ( $474 \mu M$ in water) was passed through it, the recovery was 99.4\%. Also the effect of high $\mathrm{pH}$ on the binding of urate to serum proteins was studied. The $\mathrm{pH}$ of normal serum samples (pH 7.2-7.4) was adjusted with $\mathrm{NaOH}$ to $\mathrm{pH} 10.0$ and after ultrafiltration the urate binding turned out to decrease to approximately 7\%.

Some serum samples showed turbidity, as judged from visual inspection. Thase samples were rapidly passed through a Millipore filter (Millex $\left.{ }^{\mathrm{R}}, 0.22 \mu \mathrm{m}\right)$. This did not affect the recoveries.

Serum samples from six healthy controls were assayed for uric acid using the isotachophoretic method and the enzymatic method. The samples were used either directly or after ultrafiltration. The serum uric acid values obtained with both methods showed an acceptable correlation (Table II): correlation coefficient 0.98 . Twelve to twenty eight per cent of the uric acid seemed to be associated with macromolecules of molecular weight exceeding 25,000 . The day-to- 
TABEE II

ESOTACHOPHORETC AND ENZYMATIC DETERMINATION OF URIC ACID IN SERA FROM SIX HEAETHY CONTROLS

\begin{tabular}{|c|c|c|c|c|c|c|}
\hline \multirow[t]{2}{*}{ No } & \multicolumn{3}{|c|}{ Isotachophoresis } & \multicolumn{3}{|c|}{ Enzymatic method } \\
\hline & $\begin{array}{l}\text { NEt } \\
(\mu M)\end{array}$ & $\begin{array}{l}\mathrm{UE}^{\star *} \\
(\mu M)\end{array}$ & $\begin{array}{l}\text { Bound } \\
(\%)\end{array}$ & $\begin{array}{l}\text { NFt } \\
(\mu M)\end{array}$ & $\begin{array}{l}U F^{* t} \\
(\mu M)\end{array}$ & $\begin{array}{l}\text { Bound } \\
(\%)\end{array}$ \\
\hline 1 & 374 & 329 & 12 & 390 & 303 & 22 \\
\hline $\mathbf{2}$ & 392 & 282 & 28 & 383 & 283 & 26 \\
\hline $\mathbf{3}$ & 294 & 224 & 24 & 292 & 233 & 20 \\
\hline 4 & 483 & 415 & 14 & 483 & 400 & 17 \\
\hline 5 & 361 & 298 & 17 & 375 & 317 & 15 \\
\hline 6 & 463 & 385 & 17 & 498 & 365 & 27 \\
\hline
\end{tabular}

$\begin{aligned}{ }^{\star} \text { NF } & =\text { not ultrafiltered. } \\ \star \star \text { UF } & =\text { ultrafiltered (CF } 25) . \\ \star \star \star \text { Bound } & =\text { the percentage of uric acid removed by ultrafiltration. }\end{aligned}$

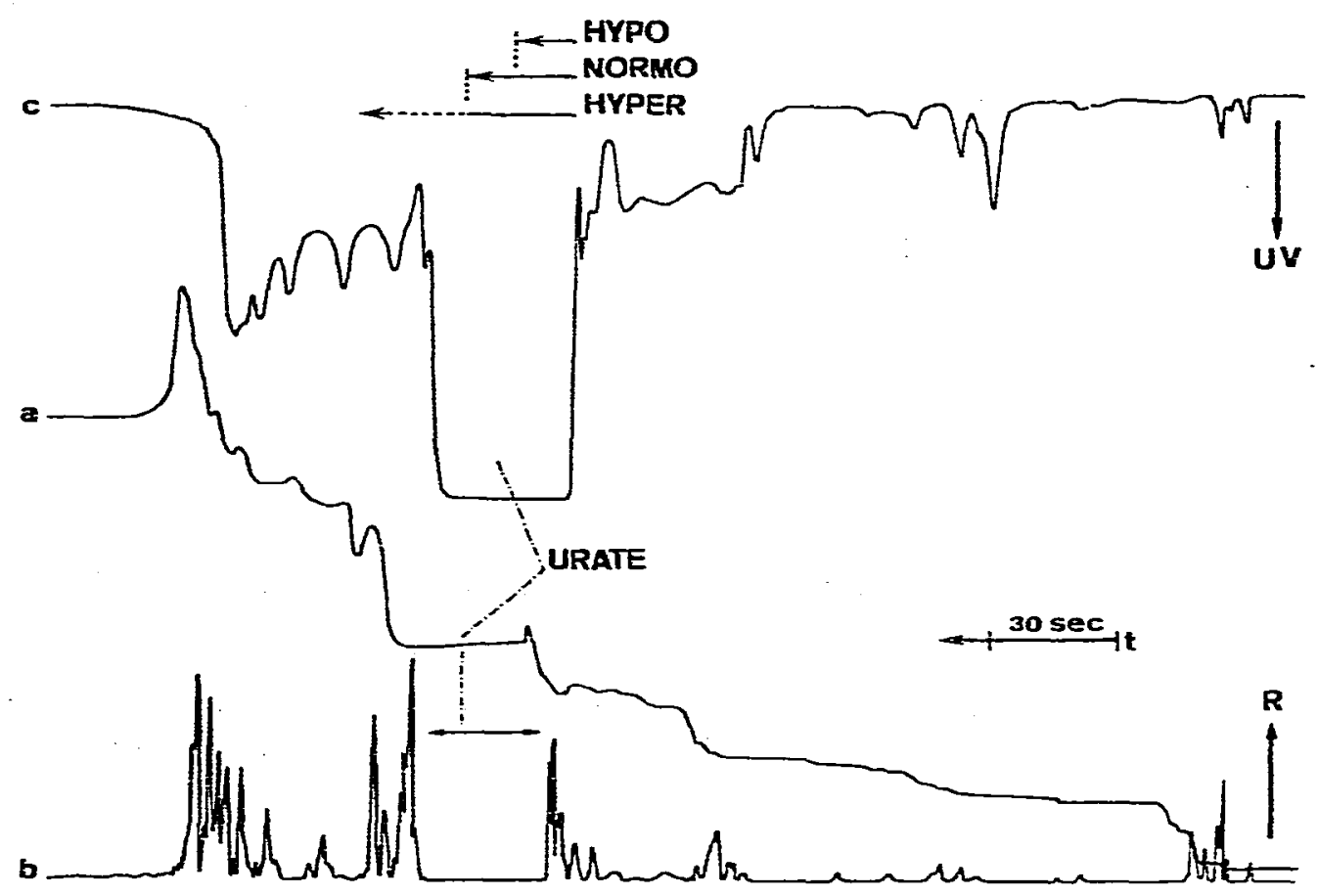

Fig. 2. Isotachophoretic separation of a hyperuricemic serum. The horizontal arrows give the uric acid zone lengths of hypo-, normo-and hyperuricemic sera under standardised operational conditions (Table I). a: conductivity signal, $R=$ increasing resistance. $b$ : differential signal of the conductivity signal. e: UV signal, transmission at $280 \mathrm{~nm}$.

day variation for a repeatedly tested sample was ca. $2 \%$ with the isotachophoretic method and ca. $10 \%$ with the enzymatic method.

The uric acid zone length is directly representative of the serum concentration under the present operational conditions. In hypo-uricemic sera the zone length will be less than $13.5 \mathrm{~mm}$. Norno- and hyperuricemic sera will give zones of up to $25 \mathrm{~mm}$ and longer than $25 \mathrm{~mm}$, respectively (Figs. 1 and 2). 


\section{TABEE III}

THE BFEECT OF HOMOGENTISIC ACD ON URIC ACD DETERMINATION BY ISOTACHOPHORESIS AND THS ENZYMATIC METHOD

\begin{tabular}{lll}
\hline Addition & $\begin{array}{l}\text { Isotachophoresis } \\
(\mu M)\end{array}$ & $\begin{array}{l}\text { Enzymatic method } \\
(\mu M)\end{array}$ \\
\hline None & 348 & 348 \\
O.5 g/ homogentisic acid & 348 & 364 \\
5.0 g/ homogentisic acid & 346 & 676 \\
\hline
\end{tabular}

TABLE IV

SERUM URIC ACD CONCENTRATIONS IN HYPERURICEMIC PATIENTS RECEIVING VARIOUS DRUGS

\begin{tabular}{llll}
\hline Diagnosis & Medication & Uric acid $(\mu M)$ & \\
\cline { 2 - 4 } & & Enzymatic method & Isotachophoresis \\
\hline Gout (male, age 63) & Zyloric & 286 & 299 \\
$\begin{array}{l}\text { Rheumatoid arthritis } \\
\begin{array}{l}\text { with hyperuricemia } \\
\text { (female, age 68) }\end{array}\end{array}$ & $\begin{array}{l}\text { Hygroton, Selokene, } \\
\text { Penicillinamide, } \\
\text { Indocid Seresta }\end{array}$ & 620 & 647 \\
$\begin{array}{l}\text { Rheumatoid arthritis } \\
\begin{array}{l}\text { with hyperuricemia } \\
\text { (female, age 44) }\end{array}\end{array}$ & $\begin{array}{l}\text { Baktrimel, Primnison, } \\
\text { Torecan }\end{array}$ & 356 & 366 \\
\hline
\end{tabular}

Several metabolites and drugs can interfere with the enzymatic determination of uric acid. An example is homogentisic acid, a compound which occurs in increased quantities in sirine of patients with alkaptonuria, an inborn error of amino acid metabolism $[13,14]$. When unphysiologically high amounts of homogentisic acid were added to samples, no effect on the isotachophoretic determinations was seen. However, with the enzymatic method higher values than those actually present were recorded (Table III).

Serum uric acid values in three initially hyperuricemic rheumatologic patients, who were treated with a number of drugs, were in close agreement when determined by both procedures (Table IV). None of the crugs seemed to interfere with the uric acid determination according to both methods.

\section{DISCUSSION}

The present isotachophoretic method for the determination of uric acid levels in serum is quantitative, reliable and reproducible (Fig. 1). In contrast to the general practice in HPLC [6] there is no need for deproteinisation: the samples can be applied directly. However, also a HPLC system without deproteinisation has been described [5] . It should be pointed out here, that in HPLC it is sometimes difficult to predict the retention behaviour of a given compound. In isotachcphoresis this is more predictable on the basis of the $p K_{a}$ values and mobilities of the compounds under study. An additional advantage of isotachophoresis over HPLC is the flexibility of the system: no column packing and equilibration is necessary if rapid switehing from one electrolyte 
system to another is needed when different conditions have to be tested. Once an electrolyte system has been chosen the isotachophoretic analyses can be done with very low day-to-day variations $(<2 \%)$. This value is lower than that obtained with the enzymatic method with a common day-to-day variation of 5-6\% [15]. At the present time the isotachophoretic serum uric acid determination is more accurate than the enzymatic method, although the latter is faster when automated.

The physiological significance of the binding of urate to plasma proteins is still disputed. Reversible interactions between urate and serum albumin, lowdensity $\beta$-lipoprotein, $\beta_{2}$-macroglobulins and $\alpha_{1}, \alpha_{2}$-globulin have been reported $[16,17]$.

Percentages of $20-40 \%$ of bound urate have been described under different conditions of temperature, ionic strength, buffers, etc. $[16,18,19]$. Our values agree with these data (Table II). Reduced binding capacity of plasma proteins might lead to higher levels of free uric acid; in patients with gout such a decreased binding capacity has been reported $[16,18]$. It has also been shown that several drugs, such as salicylates, phenylbutazone and probenecid, reduce urate binding in vitro [20]. It should be stressed, however, that all of these studies, including our own, were done under non-physiological conditions. Therefore, no conclusion can be drawn regarding the physiological significance, especially because in vivo measurements have shown that at $37^{\circ} \mathrm{C}$ the percentage of urate bound is small [21].

Homogentisic acid is a metabolite which occurs in increased quantities in the urine of alkaptonuric patients. It interferes with the enzymatic uric acid determination at $\mathbf{3 4 0} \mathrm{nm}$ by causing lower values than those actually present to be recorded [4]. No effect was seen with isotachophoresis in the presence of homogentisic acid, whereas increased levels were read with the enzymatic procedure carried out with the bichromatic (380 and $340 \mathrm{~nm}$ ) analyser ABA-100 (Table III). No attempts were made to elucidate this experimentally, but the differences might be attributed to the use of a bichromatic analyser in the present study, in contrast to a monochromatic determination at $340 \mathrm{~nm}$ only [4] .

A number of drugs used in the treatment of three initially hyperuricemic patients did not interfere with any of the methods employed: the uric acid values obtained were comparable (Table IV).

The usefulness of isotachophoresis in screening for inborn errors of purine and pyrimidine metabolism by analysing urinary bases and nucleosides has already been demonstrated [8]. We have recently developed operational systems for the analysis of purine and pyrimidine nucleosides and bases in serum [22] For both experimental and clinical purposes an alternative analytical approach is opened up, such as for the pharmacokinetic analysis of drug metabolism, or in tracing the consequences of metabolic disturbances using body fluids and cell lysates.

\section{ACKNOWLEDGEMENTS}

The authors thank Mrs. Gerrie Steenbergen (Department of Neurology, University Hospital, Nijmegen, The Netherlands) for the enzymatic analysis of uric acid on the ABA-100 analyser, and Dr. L. v.d. Putte (Department of Internal 
Medicine, Division of Rheumatology, University Hospital, Nijmegen, The Netherlands) for his cooperation in the study on the hyperuricemic patients.

\section{REFERENCES}

1 J.B. Wyngaarden and W.N. Kelley, in J.B. Stanbury, J.B. Fyngaarden and D.S. Fredrickson (Editors), The Metabolic Basis of Inherited Disease, McGraw Hill, New York, 4th ed., 1978, p. 916.

2 D.S. Newcombe, Inherited Biochemical Disordess and Uric Acid Metabolism, University Park Press, Baltimore, MD, 1975.

3 L. Liddle, J.E. Seegmiller and L. Laster, J. Lab. Clin. Med., 54 (1959) 903.

4 R. Haeckel, J. Clin. Chem. Clin. Biochem., 14 (1976) 101.

5 W.D. Slaunwhite, L.A. Pachlan, D.C. Wenke and P.T. Kissinger, Clin. Chem., 21 (1975) 1427.

6 J.A. Milner and E.G. Perkins, Anal. Biochem., 88 (1979) 560.

7 D.C. Gower and R.C. Woleoge, Sci. Tools, 24 (1977) 17.

8 A. Sahota, H.A. Simmonds and R.H. Payne, J. Pharm. Methods, 2 (1979) 303.

9 F.M. Ereraerts, J.L. Beckers and Th.P.E.M. Verheggen, Isotachophoresis: Theory. Instrumentation and Applications, Elsevier, Amsterdam, Oxiord, New York, 1976.

10 N. Kageyama, Clin. Chim. Acta, 31 (1971) 421.

11 F.M. Everzerts, Th.P.E.M. Verheggen and F.E.P. Mikkers, J. Chromatogr., 169 (1979) 21.

12 Th.P.M. Verheggen, F.E.P. Mikkers and F.M. Everaerts, Protides Biol. Fluids, 27 (1980) 723.

13 A.E. Garzod, Inborn Errors of Metabolism, Frowde, Hodder and Stoughton, London, 1909.

14 B.N. la Du, V.G. Zannoni, L. Laster and J.E. Seegmiller, J. Biol. Chem., 230 (1958) 251.

15 K. Iamers, Department of Neurology, University Hospital, Nijmegen, personal communication.

16 J.O. Alvsaker, Scand. J. Clin. Lab. Invest., 17 (1965) 467.

17 J.O. Alesaker, J. Clir. Lab. Invest., 18 (1966) 227.

18 J.R. Klinenberg ard I. Kippen, J. Lab. Clin. Med., 75 (1970) 503.

19 P.C. Farrell, R.D. Popovich and A.L. Babb, Biochim. Biophys. Acta, 243 (1971) 49.

20 R. Bluestone, I. Kippen, J.R. Klinenberg and M.T. Whitehouse, J. Lab. Clin. Med., 76 (1970) 85.

21 A.E. Postlethwaite, R.A. Gutman and W.N. Kelley, Metabolism, 23 (1974) 771.

22 F. Oerlemans, Th. Verheggen, F. Mikkers, F. Everzerts and C. de Bruyn, Adv. Erp. Med. Biol., $122(1980)$ in press. 